\title{
Challenges and perspectives to enhance cattle production via in vitro techniques: focus on epigenetics and cell-secreted vesicles
}

\author{
Desafios e perspectivas na produção in vitro de embriões bovinos: enfoque \\ epigenético e em vesículas secretadas por células
}

\author{
Fabiana Fernandes Bressan ${ }^{\mathrm{I} *}$, II Paulo Fantinato-Neto ${ }^{\text {II, III }}$ Gabriella Mamede Andrade \\ Juliano Rodrigues Sangalli, II Rafael Vilar Sampaio ${ }^{I, \text { II }}$ Juliano Coelho da Silveira \\ Felipe Perecin ${ }^{\mathrm{I}, \mathrm{II}}$ Flávio Vieira Meirelles ${ }^{\mathrm{I}}$ II
}

\section{- REVIEW -}

\section{ABSTRACT}

This review aim to present some clinical problems found in IVP-derived animals focusing on NT procedures and to discuss the possible role of epigenetics in such process. Also, as cell-secreted vesicles have been reported as possible regulators of important physiological reproductive processes such as folliculogenesis and fertilization, it is also presented herein a new perspective of manipulating the pre-implantation period trough effector molecules contained in such vesicles.

Key words: embryo development, nuclear transfer, epigenetics, extra-cellular vesicles.

\section{RESUMO}

Nesta revisão, apresentamos alguns problemas clínicos encontrados nos animais derivados de PIV, principalmente derivados de transferência de núcleo, e discutimos o possível papel da epigenética em tais processos. Além disso, uma vez que vesiculas secretadas por células têm sido descritas como possiveis reguladores de processos reprodutivos fisiológicos importantes, tais como a foliculogênese e a fertilização, estas são aqui apresentadas como uma possível nova ferramenta para a manipulação do periodo embrionário pré-implantacional através de moléculas efetoras, contidas em tais vesículas.

Palavras-chave: desenvolvimento embrionário, transferência de núcleo, epigenética, vesículas extra-celulares.

\section{INTRODUCTION}

Reproductive biotechniques are largely used for solving possible reproductive failures in both human and veterinary medicine. Also, they comprise important tools for animal breeding once they may facilitate a faster genomic selection of high quality animals. The in vitro embryo production (IVP) is particularly important for providing the basic procedures needed in other biotechniques such as in vitro fertilization (IVF), intracytoplasmic sperm injection (ICSI) and cloning (nuclear transfer - NT). The IVP in cattle has showed impressive improvements in the last years, and data from the International Embryo Transfer Society (IETS) shows that $85 \%$ of all embryos transfers of IVPproduced embryos were produced in Brazil in 2011 (IETS, 2012).

However the IVP system is technically viable and already a routine in animal production, there are still critical limitations. The in vitro produced embryos present lower developmental rates when compared to in vivo production systems. After IVF, only 40 to $50 \%$ of oocytes are competent to reach the blastocyst stage (RIZOS et al., 2002).

Frequently, the pregnancies derived from IVP processes that are maintained to term results in offspring presenting several healthy disorders, some of them closely related to epigenetic disorders, but most still without well known causes. It has been discussed that embryo IVP is routinely accompanied by epigenetic problems mostly in consequence of in vitro culture (LAZARAVICIUTE et al., 2014). Therefore, herein the authors aim to present some clinical problems found in IVP-derived animals

\footnotetext{
IDepartamento de Medicina Veterinária, Faculdade de Zootecnia e Engenharia de Alimentos (FZEA), Universidade de São Paulo (USP), 13635-000, Pirassununga, SP, Brasil. E-mail: fabianabressan@usp.br. "Corresponding author.

IIDepartamento de Cirurgia, Faculdade de Medicina Veterinária e Zootecnia (FMVZ), USP, São Paulo, SP, Brasil.

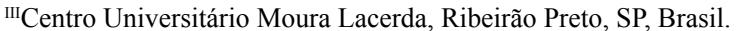


focusing on NT procedures, to discuss the possible role of epigenetics in such process and finally, to present a new perspective of manipulating the pre-implantation period trough cell-secreted vesicles.

Pre and post-natal clinical deficiencies of animals produced in vitro

The first in vitro produced calf was born in the 1980s and since then there have been great improvements in the whole process; eg. the culture media, the spermatozoa capacitation, the oocyte recovery, and the maturation and the fertilization itself have been refined (VAJTA et al., 2010). However, several failures are still concerned. Although the IVF as a laboratory technique is well established, there are some unsolved questions, which in turn, are also very similar to those found in NT procedures.

The IVF technique presents a birth rate ranging from $40 \%$ to $60 \%$. Gestational losses generally occur in the first trimester, until 90 days of gestation. Although its benefits, the in vitro production of cloned animals by NT is inefficient (VAN WAGTENDONKDE LEEUW et al., 1998; MEIRELLES et al., 2010); the birth rate is approximately $5 \%$ or less of transferred blastocysts. The competence of in vitro produced blastocysts is a critical stage of the NT process. The rate of reconstructed oocytes that are capable of developing until blastocyst stage may range from $15 \%$ to almost $50 \%$ of the number of oocytes that had nuclear fusion completed (LONERGAN et al., 2007). Significant losses are observed regarding the ability of maintaining healthy pregnancies and production of healthy offspring; and these along with several other factors are responsible for the high-costs involved in NT technique.

Indeed, abnormal placentation and clinical problems on offspring are some of the observations found on IVP- produced calves, most pronouncedly in NT-derived animals. In the intra uterine life, the uterus environment provides everything that the conceptus need for being alive initially. After a few weeks, at around days 30 to 50 , the placentation is initiated and than the fetus nutrition is provided by the placenta (CARTER, 1999; BRESSAN et al., 2009). However, in NT and IVF gestations, the cotyledons formation is impaired and the cotyledon-caruncle interactions fail in successfully form the placentomes, resulting in fewer and larger placentomes (BERTOLINI \& ANDERSON, 2002; CHAVATTE-PALMER et al., 2012).

With such morphological abnormal placentation, functional abnormalities come along. The glucose transportation to the fetus is impaired, where the fetal fluids has reduced levels of glucose and fructose. Also, the abnormal placenta does not produce steroid hormones as it should. Finally, it is often observed abnormal embryo development when using NT or other assisted reproduction techniques and the inability to maintain alive full-term progeny mainly after NT, and these outcomes may be a result of failure during epigenetic reprogramming (NIEMANN et al., 2008; CHAVATTE-PALMER et al., 2012).

Several others studies on placental and neonatal alterations are reviewed in Smith and collaborators, 2012 (SMITH et al., 2012). Recent studies revealed severe cardio-respiratory disorders in newborn cloned calves, mostly characterized by hyperphonesis, heart sound reinforcement, presence of heart murmurs in $1^{\text {st }}$ and $2^{\text {nd }}$ sounds associated with dyspnea, rude breathing, crackles and decreased values of $\mathrm{PO}_{2}$ from the arterial blood (BIRGEL JUNIOR et al., 2011). Despite the implementation of neonatal intensive care in cloned calves, many animals are born with clinical conditions that are not easily reversed. A huge number of newborn clones present clinical and morphological signs that can be related to syndromes caused by epigenetic alterations during the IVP process.

The large offspring syndrome (LOS) is a typical phenotype on calves derived from ARTs (FARIN et al., 2006). LOS is an overgrowth disorder in ruminants which is phenotypically similar to Beckwith-Wiedemann syndrome (BWS) in humans (CHEN et al., 2013). The features of LOS and BWS include: excessive birth weight, large tongue, umbilical hernia, hypoglycemia, and visceromegaly. It is known that both BWS and LOS are characterized by the loss of imprinting on IGF2 gene, causing biallelic overexpression and a lack of expression of H19 gene, and such epigenetic alterations have been observed in ART produced bovine conceptuses, including NT-derived calves (HORI et al., 2010). Other epigenetic-related syndromes are also observed in IVP offspring, for example, in the Russell-Silver syndrome (RSS) which is characterized by the loss of methylation in IGF2-H19 ICR, reduction in IGF2 expression, and biallelic expression of $\mathrm{H} 19$, resulting in intrauterine and post-natal growth retardation, the opposite of LOS and BWS (BLIEK et al., 2006).

Epigenetic mechanisms of natural reprogramming versus cloning

Epigenetic is the structural adaptation of chromosomal regions in order to register, signal or perpetuate altered activity states (BIRD, 2007). In other words, genes can behave differently in different cells, and pass such behavior to the next 
generation. This feature can be observed during embryo development, in which cells switch genes for specialization (LAW \& JACOBSEN, 2010).

PORTELA \& ESTELLER, in 2010, suggested grouping the epigenetic mechanisms into three main categories: DNA methylation, histone modifications and nucleosome positioning, highlighting the interplay between epigenetic factors. Noncoding RNAs have also been described as an epigenetic mechanism (BERNSTEIN \& ALLIS, 2005). Probably the most studied epigenetic mechanism is the DNA methylation, once it is the most stable and the principal regulator of epigenetic inheritance across generations (NG \& GURDON, 2005). It is related to different cancer types, since global hypomethylation, inducing genomic instability, also contributes to cell transformation, and consists in a covalent addition of methyl group at the 5-position of cytosine base (5-methylcytosin), within the dinucleotide $\mathrm{CpG}$ islands by methyltransferases enzymes (Dnmts) (GEIMAN \& ROBERTSON, 2002).

The DNA methylation level is associated to the degree of cell differentiation. During the fertilization, highly methylated maternal and paternal pronuclei undergo a demethylation process (SANTOS et al., 2002). This procedure is essential for the embryo development, in which new methylation marks will be created. However, the demethylation pattern is different in each parental chromatin, while maternal genome is slowly and passive, the paternal is fast and active (MAYER et al., 2000; OSWALD et al., 2000). For a long time the active process was unknown, however in 2011 studies showed that the responsibility for such process is the formation of 5-hydroxymethylcytosine (5-hmc), a cytosine variation, in which a $-\mathrm{OH}$ is added to the methylated cytosine by a protein from the Tet family; Tet 1, 2 or 3 (IQBAL et al., 2011; WOSSIDLO et al., 2011). Tet 1 and 2 have been related to embryonic stem cells pluripotency and depletion of Tet 1 implicates in lineage differentiation difficulties (COSTA et al., 2013). Additionally, Tet 1 was detected in primordial germ cells highlighting its role in an undifferentiated profile (HAJKOVA et al., 2010), and Tet 3 is highly expressed in both oocyte and zygote, being responsible for 5-hmc increase on paternal pronucleus, while the maternal genome is protected by binding to PGC7 protein (also known as Dppa3 or Stella) (IQBAL et al., 2011; WOSSIDLO et al., 2011).

However essential for the epigenetic reprogramming, DNA demethylation of somatic cell when transferred to enucleated oocyte is partial. The reestablishment of methyl marks on de novo methylation occurs prematurely (REIK et al., 2001).
Similar to fertilization, 5-hmc has been reported in somatic cell reprogramming, after cell injection, to be increased on somatic nucleus (WOSSIDLO et al., 2011). Nevertheless, little is known about its role.

Changes on histone pattern are also associated to failure on nuclear reprogramming. The main histone variation in SCNT is in the methylation of lysine 9 on histone H3 (H3K9) (SANTOS et al., 2003). The principal enzyme responsible for the di methylation of H3K9 is G9a. Besides the activity on histone, G9a expression has been shown as a DNMT1 coworker, binding the activity to DNA methylation levels (ESTĖVE et al., 2009). Furthermore, G9a itself is capable of rousing de novo methylation by recruiting Dnmt3a and Dnmt3b independently of its histone methyltransferase activity (EPSZTEJNLITMAN et al., 2008).

Barriers restricting reprogramming of somatic nuclei and strategies to improve cloning by SCNT

As described above, there are several epigenetic modifications that accompany cell differentiation, including DNA methylation, histone modifications i.e. H3K 9 me $2 / 3$ methylation, histone deacetylation, incorporation of histone variants (e.g. macroH2A) and chromatin compaction. These modifications may act as epigenetic barriers when somatic cell nuclei are submitted to in vitro reprogramming techniques such as SCNT (PASQUE et al., 2010; 2011). Since histone deacetylation, followed by DNA compaction, is commonly associated with gene repression in differentiated cells, decondensation of chromatin is required to enable the access of transcriptional regulators to genomic targets essential for successful reprogramming the somatic nuclei (HEZRONI et al., 2011). Corroborating this hypothesis, most factors that promote chromatin decondensation, including histone deacetylase inhibitors (HDACis), have been found to increase nuclear reprogramming efficiency, making their use common to improve SCNT rates (KISHIGAMI et al., 2006).

There are two postulated mechanisms explaining how hyperacetylation works on gene expression: 1- disrupting the electrostatic interaction between the histone and the DNA backbone (neutralizing the positive charges of histones) and 2- acting as a docking site for the recruitment of transcriptional coactivators (FEDERATION et al., 2014). The enzymes that catalyze the acetylation/ deacetylation reaction are Histone acetyltransferases (HAT) and HDACs, respectively.

HDAC inhibitors have been widely used in biological studies ranging from clinical oncology 
to epigenetics (FEDERATION et al., 2014). A subset of these compounds has also been used in studies for stem cell and nuclear reprogramming (HUANGFU et al., 2008). The most extensively studied HDAC inhibitors in the context of reprogramming are trichostatin A (TSA) and valproic acid (VPA).

The first manuscript reporting success using HDACis in SCNT was published in 2006 (KISHIGAMI et al., 2006). An increase of up to five fold in the success rate of mouse cloning was observed. Since then, a flurry of papers were published showing the effect of HDACis on SCNT in different species (MONTEIRO et al., 2010). The results are promising, but in some species such as bovine, remains highly controversial (AKAGI et al., 2013; GALLI et al., 2014). The majority of reports have addressed the effects on pre-implantation stages only. The long gestation period in cattle and the high cost to produce pregnancies makes these data scarce. At this moment, there are no reliable markers of embryo competence, and the best way to evaluate the outcomes after HDACis treatment is transfer the embryos to surrogate cows.

Recently our group addressed this question using HDACis on SCNT in cattle and observing the embryo development throughout gestation, aiming to provide insight into post blastocyst development since most studies on this topic stop at blastocyst development as the end point. This data showed that treatment with HDACis such as TSA or VPA did not improved the full-term development in cattle clones. However, the treatment did not prevent pregnancy establishment, did not appear to increase or decrease that rate of loss (60 to 270 day) or development to term. Also the level of abnormalities was not higher that in controls (SANGALLI et al., 2012, 2014).

Accumulated evidence suggests that HDACis are highly important to aid nuclear reprogramming with a consequent increase in SCNT efficiency in mice (OGURA et al., 2013). This improvement, in swine, was recently awarded in the HDACis`s ability on DNA damage repair mechanism. The authors showed that DNA damage on nuclear donor might negatively affect the SCNT embryo development, however, treatment with HDACis was able to recover the embryo development (BOHRER et al., 2014). In cattle, the use of HDACis remains largely controversial (AKAGI et al., 2013). In the future, combining technologies such as iPS cells and SCNT as a strategy to improve the outcomes may be interesting. Also, dissecting the roles that HDAC plays in donor cells and cloned embryos may lead to mechanistic insights on their use.
New perspective: extracellular vesicles containing bioactive molecules might regulate gametes quality and pregnancy outcome

Extracellular vesicles are present in different body fluids including seminal plasma, ovarian follicular fluid and uterine fluid (TANNETTA et al., 2014). Cellsecreted vesicles containing bioactive molecules such as miRNA, mRNA and proteins have been shown to mediate cell communication among different cell types (BURNS et al., 2014; DA SILVEIRA et al., 2014). Recently, an experiment demonstrated the transfer of cell-secreted vesicles from parthenogenetic embryos to cloned embryos, providing a new paradigm for embryo-to-embryo communication in vitro (SAADELDIN et al., 2014). Herein, this review presents new perspectives on the role of cell-secreted vesicles during female gamete development as well as during pre-implantation period. Thus, these vesicles can serve as markers for gametes quality as well as modulators of embryo contents.

For the purpose of this review, it was focused on two types of cell-secreted vesicles called microvesicles (MV) and exosomes (EXO) and its role in reproduction. MV are considered membrane vesicles with a size around up to $\sim 1000 \mathrm{~nm}$ and EXO are between $\sim 40-150 \mathrm{~nm}$ with cell-type dependent variations. They also are distinguished based on biogenesis pathway; MV from the plasma membrane and EXO originate from within multivesicular bodies (MVB) and are secreted by fusion of MVB with the plasma membrane (RAPOSO \& STOORVOGEL, 2013).

These two populations of cell-secreted vesicles also differ in content. The cell-secreted vesicles contain material that mirror the genetic and proteomic content of the secreting cell (AKERS et al., 2013). In general, MV contains plasma membrane proteins (Anexin V) and intracellular proteins, mRNA, and miRNA. EXO are enriched with tetraspanin proteins (CD63, CD9, CD81), and also contain mRNAs and miRNAs. MV and EXO share similar functions. MV main functions include procoagulant activity, pro-invasive character of tumors, induction of oncogenic cellular transformation, and fetomaternal communication. EXO main functions involve antigen-presentation, stimulating antitumoral immune responses, sperm-egg interaction and feto-maternal communication. Compelling evidence supports the significance of these vesicles in a broad range of physiological and pathological processes (RAPOSO \& STOORVOGEL, 2013).

In order to produce an oocyte capable to be fertilized, intercellular communication is important. In the female ovary, EXO and MV were described to 
be present in ovarian follicular fluid of equine, bovine and in human, and initially described in follicular fluid using transmission electron microscopy and flow cytometry (SANG et al., 2013; SOHEL et al., 2013).

Subsequent experiments included treating cultured granulosa cells with fluorescent-labeled $\mathrm{MV}$ in order to verify the up take of these vesicles by granulosa cells in vitro and in vivo. miRNAs and proteins were identified in these cell-secreted vesicles: miRNA-181a, miR-375, and miR-513a-3p levels in follicular fluid EXO were significantly higher in old compared to young mares (DA SILVEIRA et al., 2012). Furthermore, miRNA profiling of exosomes isolated from bovine follicular fluid uncovered miRNAs associated with oocyte cytoplasmic maturation, suggesting that follicular fluid-derived exosomal miRNAs can be used as a biomarker for oocyte quality (SOHEL et al., 2013).

In humans, exosomal miRNAs present in follicular fluid were associated with hormonal concentrations, such as miR-132, miR-320, miR$520 \mathrm{c}-3 \mathrm{p}, \mathrm{miR}-24$, and miR-222 involved in the regulation of estradiol concentrations, while miR24 , miR-193b, and miR-483-5p are involved in the regulation of progesterone concentrations. Also, miR132 and miR-320 presented significantly decreased levels in follicular fluid of polycystic ovarian patients (SANG, 2013). Further investigation demonstrated that exosomes from mid-estrous (containing ACVR1 and miR-27b) were capable to transfer their contents to granulosa cells. These results lead to the hypothetical model that exosomes mediate the differentiation of granulosa cells from mid-estrus to pre-ovulatory follicles through the acquisition of ACRV1, thus amplifying cell differentiation and LHr acquisition before ovulation. It is evident that cellsecreted vesicles (MV, EXO) are present in follicular fluid and contain miRNAs. Furthermore, these cellsecreted vesicles likely have an intrafollicular origin, and can be taken up by surrounding granulosa cells.

Still, the development of vesicles signatures and profiling studies are necessary to identify the origin of the different cell-secreted vesicles within the follicular fluid. In order to respond some of the questions it was identified exosomes and microvesicles in follicular fluid of bovine ovarian follicles using Transmission Electron Microscopy (TEM), RNA profile and tunable resistance pulse sensing, confirming the presence of both EXO and MV. TEM micrographs demonstrated the presence of multivesicular bodies within granulosa cells and cumulus cells, suggesting that both cell types can secrete exosomes (ANDRADE et al., 2014 unpublished data).
Establishment of pregnancy in mammals is determined by the maternal recognition and the crosstalk between the conceptus and the mother is extremely important. Exosomes were identified in uterine fluid from sheep at day 14 of the cycle during the pregnancy recognition period in ovine. EXO described in uterine fluid contained miRNA, mRNA and proteins such as CD63 and HSP70 (exosome markers). Different mRNAs were identified in EXO from pregnant and cyclic ewes, among them the endogenous beta retrovirus (enJSRVs), enJSRVs mRNA is produced in the endometrium and is important for throphectoderm differentiation, thus suggesting that EXOs are mediating this process (BURNS et al., 2014).

Furthermore, embryo development is critical during somatic cell nuclear transfer (SCNT) and the consequence is the number of embryos produced. A mechanism to improve is performing embryo coculture systems between nuclear transfer (NT) embryos and somatic cells, offering the paracrine effects of the in vivo embryo development (SAADELDIN et al., 2014). To test the hypothesis that extracellular vesicles play an important role and can improve porcine SCNT embryo production, a co-culture system using parthenogenetic (PA) embryos in the bottom of the well with NT emrbyos on top separated by a filter was developed. In this experiment the co-cultured system of PA/NT embryos demonstrated to improve cleavage rate and blastocyst rate compared to NT/ NT embryo system. Also, transcripts for OCT4, KLF4 and $N A N O G$ were identified in extracellular vesicles isolated from the cell culture media of PA embryos; additionally, levels of these transcripts were increased in NT embryos following the co-culture with PA embryos. Furthermore, it was demonstrated that these extracellular vesicles could be up take by NT embryos independent of the zona pellucida presence, demonstrating that these vesicles are capable of crossing this structure (SAADELDIN et al., 2014). Thus, these results demonstrate that extracellular vesicles can mediate cell communication and improve embryo development in vitro during the preimplantation period.

\section{CONCLUSION}

Once in vitro techniques are proved to interfere with imprint establishment (manipulation of gametes) or imprint maintenance (manipulation of pre-implantation embryos), herein it was reviewed the basic mechanisms of epigenetic reprogramming, and further discussed how to manipulate the pre- 
implantation period in order to prevent or correct the undesirable phenotypes discussed above. In future experiments it is important to understand the mechanisms behind loading, secretion, uptake and delivery of EXO and MV during spermatozoa capacitation, follicular development and pregnancy establishment in order to develop new tools to study and manipulate the entire gamete manipulation and embryo pre-implantation periods.

\section{ACKNOWLEDGEMENTS}

The authors would like to acknowledge Conselho Nacional de Desenvolvimento Científico e Tecnológico (CNPq) grants $\mathrm{n}^{\circ}$ 482163/2013-5, 479135/2013-4, 573754/2008-0 and Fundação de Amparo à Pesquisa do Estado de São Paulo (FAPESP) grants n ${ }^{\circ}$ 2013/08135-2 Centros de Pesquisa, Inovação e DifusãoCentro de Terapia Celular (CEPID-CTC), 2008/57877-3 Instituto Nacional de Ciência e Tecnologia em Terapia Celular (INCTC), 2014/21034-3 for financial support.

\section{REFERENCES}

AKAGI, S. et al. Recent progress in bovine somatic cell nuclear transfer. Animal science journal, v.84, n.3, p.191199, Mar. 2013. Available from: <http://www.ncbi.nlm.nih. gov/pubmed/23480698>. Accessed: Jul. 09, 2014. doi:10.1111/ asj. 12035.

AKERS, J.C. et al. Biogenesis of extracellular vesicles (EV): exosomes, microvesicles, retrovirus-like vesicles, and apoptotic bodies. Journal of neuro-oncology, v.113, n.1, p.1-11, May, 2013. Available from: <http://www.ncbi.nlm.nih.gov/ pubmed/23456661>. Accessed: Jul. 09, 2014. doi:10.1007/s11060013-1084-8.

BERNSTEIN, E.; ALLIS, C.D. RNA meets chromatin. Genes \& development, v.19, n.14, p.1635-1655, jul. 2005. Available from: $<$ http://www.ncbi.nlm.nih.gov/pubmed/16024654>. Accessed: Jul. 09, 2014. doi:10.1101/gad.1324305.

BIRD, A. Perceptions of epigenetics. Nature, v.447, n.7143, p.396-398, May, 2007. Available from: <http://www.ncbi.nlm.nih. gov/pubmed/17522671>. Accessed: Jul. 09, 2014. doi:10.1038/ nature 05913 .

BIRGEL JUNIOR, E.H. et al. Clinical disorders observed during the first 30 days of life of cloned Zebu calf. Acta Scientiae Veterinariae, v.39, suppl.1, p.s243-s252, 2011. Available from: $<$ http://www.ufrgs.br/actavet/39-suple-1/30 Supl_s243-s252.pdf>. Accessed: Jul. 16, 2014.

BLIEK, J. et al. Hypomethylation of the H19 gene causes not only Silver-Russell syndrome (SRS) but also isolated asymmetry or an SRS-like phenotype. American journal of human genetics, v.78, n.4, p.604-614, Apr. 2006. Available from: <http://www. pubmedcentral.nih.gov/articlerender.fcgi?artid=1424698\& too l=pmcentrez\&rendertype $=$ abstract $>$. Accessed: Jul. 16, 2014. doi:10.1086/502981.

BOHRER, R.C. et al. Inhibition of histone deacetylases enhances DNA damage repair in SCNT embryos. Cell Cycle, v13 n.13, p.2138-2148, Jul. 2014. Available from: <http://www.ncbi. nlm.nih.gov/pubmed/24841373>. Accessed: Jul. 02, 2014. doi: $10.4161 /$ cc. 29215

BRESSAN, F.F. et al. Unearthing the roles of imprinted genes in the placenta. Placenta, v.30, n.10, p.823-834, Oct. 2009. Available from: <http://www.ncbi.nlm.nih.gov/pubmed/19679348>. Accessed: Jul. 02, 2014. doi: 10.1016/j.placenta.2009.07.007.

BURNS, G. et al. Extracellular vesicles in luminal fluid of the ovine uterus. PloS one, v.9, n.3, p.e90913, Jan. 2014. Available from: <http://www.pubmedcentral.nih.gov/articlerender.fcgi?artid $=3948691 \&$ tool $=$ pmcentrez $\&$ rendertype $=$ abstract $>$. Accessed: Jul. 01, 2014. doi:10.1371/journal.pone.0090913.

CARTER, A.M. J.P. Hill on placentation in primates. Placenta, v.20, n.7, p.513-517, Sept. 1999. Available from: <http://www. ncbi.nlm.nih.gov/pubmed/10452904>. Accessed: Jan. 19, 2015. doi:10.1053/plac.1999.0413.

CHAVATTE-PALMER, P. et al. Review: placental perturbations induce the developmental abnormalities often observed in bovine somatic cell nuclear transfer. Placenta, v.33, Suppl, p.S99-S104, 2012. Available from: <http://www.ncbi.nlm. nih.gov/pubmed/22000472>. Accessed: Jul. 01, 2014. doi:10.1089/1536230041372274.

CHEN, Z. et al. Large offspring syndrome: a bovine model for the human loss-of-imprinting overgrowth syndrome BeckwithWiedemann. Epigenetics: official journal of the DNA Methylation Society, v.8, n.6, p.591-601, Jun. 2013. Available from: <http://www.pubmedcentral.nih.gov/articlerender.fcgi?arti $\mathrm{d}=3857339$ \&tool $=$ pmcentrez\&rendertype $=$ abstract $>$. Accessed: Jul. 09, 2014. doi:10.4161/epi.24655.

COSTA, Y. et al. NANOG-dependent function of TET1 and TET2 in establishment of pluripotency. Nature, v.495, n.7441, p.370374, Mar. 2013. Available from: <http://www.pubmedcentral.nih. gov/articlerender.fcgi? artid=3606645\&tool=pmcentrez\&renderty pe $=$ abstract $>$. Accessed: Jul. 09, 2014. doi:10.1038/nature11925.

DA SILVEIRA, J.C. et al. Cell-secreted vesicles in equine ovarian follicular fluid contain miRNAs and proteins: a possible new form of cell communication within the ovarian follicle. Biology of reproduction, v.86, n.3, p.71, Mar. 2012. Available from: <http:// www.ncbi.nlm.nih.gov/pubmed/22116803>. Accessed: Jul. 02, 2014. doi:10.1095/biolreprod.111.093252.

DA SILVEIRA, J.C. et al. Regulation of ACVR1 and ID2 by cell-secreted exosomes during follicle maturation in the mare. Reproductive biology and endocrinology: RB\&E, v.12, n.1, p.44, Jan. 2014. Available from: <http://www.pubmedcentral.nih.gov/ articlerender.fcgi? artid $=4045866 \&$ tool $=$ pmcentre $\&$ rendertype $=\mathrm{a}$ bstract>. Accessed: Jul. 02, 2014. doi:10.1186/1477-7827-12-44.

EPSZTEJN-LITMAN, S. et al. De novo DNA methylation promoted by G9a prevents reprogramming of embryonically silenced genes. Nature Structural \& Molecular Biology, v.15, n.11, p.1176-1183, Nov. 2008. Available from: <http://www. pubmedcentral.nih.gov/articlerender.fcgi?artid=2581722\& too l=pmcentrez\&rendertype $=$ abstract $>$. Accessed: Jul. 09, 2014. doi:10.1038/nsmb.1476.

ESTÈVE, P.-O. et al. Regulation of DNMT1 stability through SET7-mediated lysine methylation in mammalian cells. Proceedings of the National Academy of Sciences of the United 
States of America, v.106, n.13, p.5076-5081, Mar. 2009. Available from: <http://www.pubmedcentral.nih.gov/articlerender.fcgi?arti $\mathrm{d}=2654809$ \&tool $=$ pmcentrez\&rendertype $=$ abstract $>$. Accessed: Jul. 09, 2014. doi:10.1073/pnas.0810362106.

FARIN, P.W. et al. Errors in development of fetuses and placentas from in vitro-produced bovine embryos. Theriogenology, v.65, n.1, p.178-191, Jan. 2006. Available from: <http://www.ncbi. nlm.nih.gov/pubmed/16266745>. Accessed: Jul. 09, 2014. doi:10.1016/j.theriogenology.2005.09.022.

FEDERATION, A.J. et al. The use of small molecules in somaticcell reprogramming. Trends in Cell Biology, v.24, n.3, p.179187, Mar. 2014. Available from: <http:/www.ncbi.nlm.nih.gov/ pubmed/24183602>. Accessed: Jul. 09, 2014. doi:10.1016/j. tcb.2013.09.011.

GALLI, C. et al. Ovum pick up, intracytoplasmic sperm injection and somatic cell nuclear transfer in cattle, buffalo and horses: from the research laboratory to clinical practice. Theriogenology, v.81, n.1, p.138-151, Jan. 2014. Available from: <http://www. ncbi.nlm.nih.gov/pubmed/24274418>. Accessed: Jul. 09, 2014. doi:10.1016/j.theriogenology.2013.09.008.

GEIMAN, T.M.; ROBERTSON, K.D. Chromatin remodeling, histone modifications, and DNA methylation-how does it all fit together? Journal of cellular biochemistry, v.87, n.2, p.117-125, Jan. 2002. Available from: <http://www.ncbi.nlm.nih.gov/pubmed/12244565> Accessed: Jul. 09, 2014. doi:10.1002/jcb.10286.

HAJKOVA, P. et al. Genome-wide reprogramming in the mouse germ line entails the base excision repair pathway. Science, v.329, n.5987, p.78-82, Jul. 2010. Available from: $<$ http://www. pubmedcentral.nih.gov/articlerender.fcgi?artid $=3863715 \&$ too l=pmcentrez\&rendertype $=$ abstract $>$. Accessed: Jul. 09, 2014. doi:10.1126/science. 1187945 .

HEZRONI, H. et al. Pluripotency-related, valproic acid (VPA)induced genome-wide histone $\mathrm{H} 3$ lysine 9 (H3K9) acetylation patterns in embryonic stem cells. Journal of Biological Chemistry, v.286, n.41, p.35977-35988, 14 Oct. 2011. Available from: <http://www.pubmedcentral.nih.gov/articlerender.fcgi?arti $\mathrm{d}=3195619$ \& tool $=$ pmcentrez\&rendertype $=$ abstract $>$. Accessed: Jul. 09, 2014. doi:10.1074/jbc.M111.266254.

HORI, N. et al. Aberrant CpG methylation of the imprinting control region KvDMR1 detected in assisted reproductive technology-produced calves and pathogenesis of large offspring syndrome. Animal Reproduction Science, v.122, n.3-4, p.303312, Dec. 2010. Available from: <http://www.ncbi.nlm.nih.gov/ pubmed/21035970>. Accessed: Jul. 16, 2014. doi:10.1016/j. anireprosci.2010.09.008.

HUANGFU, D. et al. Induction of pluripotent stem cells by defined factors is greatly improved by small-molecule compounds. Nature biotechnology, v.26, n.7, p.795-797, Jul. 2008. Available from: $<$ http://www.ncbi.nlm.nih.gov/pubmed/18568017>. Accessed: Jul. 09, 2014. doi:10.1038/nbt1418.

IQBAL, K. et al. Reprogramming of the paternal genome upon fertilization involves genome-wide oxidation of 5-methylcytosine. Proceedings of the National Academy of Sciences of the United States of America, v.108, n.9, p.3642-3647, Mar. 2011. Available from: <http://www.pubmedcentral.nih.gov/articlerender.fcgi?arti $\mathrm{d}=3048122$ \& tool $=$ pmcentrez\&rendertype $=$ abstract $>$. Accessed: Jul. 09, 2014. doi:10.1073/pnas.1014033108.
KISHIGAMI, S. et al. Significant improvement of mouse cloning technique by treatment with trichostatin A after somatic nuclear transfer. Biochemical and Biophysical Research Communications, v.340, n.1, p.183-189, Feb. 2006. Available from: <http://www.ncbi.nlm.nih.gov/pubmed/16356478>. Accessed: Jul. 09, 2014. doi:10.1016/j.bbrc.2005.11.164.

LAW, J.A.; JACOBSEN, S.E. Establishing, maintaining and modifying DNA methylation patterns in plants and animals. Nature Reviews. Genetics, v.11, n.3, p.204-220, Mar. 2010. Available from: $<$ http://www.pubmedcentral.nih.gov/articlerender. fcgi artid $=3034103 \&$ tool $=$ pmcentrez $\&$ rendertype $=$ abstract $>$. Accessed: Jul. 09, 2014. doi:10.1038/nrg2719.

LAZARAVICIUTE, G. et al. A systematic review and metaanalysis of DNA methylation levels and imprinting disorders in children conceived by IVF/ICSI compared with children conceived spontaneously. Human reproduction update, 24 jun. 2014. Available from: < http://www.ncbi.nlm.nih.gov/ pubmed/24961233>. Accessed: Jul. 09, 2014. doi:10.1093/ humupd/dmu033.

LONERGAN, P. et al. Pregnancy and fetal characteristics after transfer of vitrified in vivo and cloned bovine embryos. Theriogenology, v.68, n.8, p.1128-1137, Nov. 2007. Available from: $<$ http://www.ncbi.nlm.nih.gov/pubmed/17875317>. Accessed: Jul. 09, 2014. doi:10.1016/j.theriogenology.2007.08.012.

MAYER, W. et al. Demethylation of the zygotic paternal genome. Nature, v.403, n.6769, p.501-502, Feb. 2000. Available from: $<$ http://www.ncbi.nlm.nih.gov/pubmed/10676950>. Accessed: Jul. 09, 2014. doi:10.1038/35000654.

MEIRELLES, F.V. et al. Delivery of cloned offspring: experience in Zebu cattle (Bos indicus). Reproduction, Fertility, and Development, v.22, n.1, p.88-97, Jan. 2010. Available from: $<$ http://www.ncbi.nlm.nih.gov/pubmed/20003849>. Accessed: Feb. 21, 2014. doi:10.1071/RD09229.

MONTEIRO, F.M. et al. Chromatin modifying agents in the in vitro production of bovine embryos. Veterinary Medicine International, v.2011, Article ID 694817, Jan. 2010. Available from: <http://www.pubmedcentral.nih.gov/articlerender.fcgi?arti $\mathrm{d}=2948908 \&$ tool $=$ pmcentrez $\&$ rendertype $=$ abstract $>$. Accessed . Jul. 09, 2014. doi:10.4061/2011/694817.

NG, R.K.; GURDON, J.B. Epigenetic memory of active gene transcription is inherited through somatic cell nuclear transfer. Proceedings of the National Academy of Sciences of the United States of America, v.102, n.6, p.1957-1962, Feb. 2005. Available from: <http://www.pubmedcentral.nih.gov/articlerender.fcgi?artid $=548545 \&$ tool $=$ pmcentrez\&rendertype $=$ abstract $>$. Accessed: Jul. 09,2014. doi:10.1073/pnas.0409813102.

NIEMANN, H. et al. Epigenetic reprogramming in embryonic and foetal development upon somatic cell nuclear transfer cloning. Reproduction, v.135, n.2, p.151-163, Feb. 2008. Available from: $<$ http://www.ncbi.nlm.nih.gov/pubmed/18239046>. Accessed: Jan. 19, 2015. doi: 10.1530/REP-07-0397.

OGURA, A. et al. Recent advancements in cloning by somatic cell nuclear transfer. Philosophical Transactions of the Royal Society of London. Series B, Biological Sciences, v.368, n.1609, p.20110329, Jan 2013. Available from: <http://www.pubmedcentral.nih.gov/ articlerender.fcgi? artid $=3539358 \&$ tool $=$ pmcentrez\&rendertype $=$ abs tract>. Accessed: Jul. 09, 2014. doi:10.1098/rstb.2011.0329. 
OSWALD, J. et al. Active demethylation of the paternal genome in the mouse zygote. Current Biology: CB, v.10, n.8, p.475478, Apr. 2000. Available from: <http://www.ncbi.nlm.nih.gov/ pubmed/10801417>. Accessed: Jul. 09, 2014. doi: 10.1016/ S0960-9822(00)00448-6.

PASQUE, V. et al. Epigenetic factors influencing resistance to nuclear reprogramming. Trends in Genetics: TIG, v.27, n.12, p.516-525, Dec. 2011. Available from: <http://www. pubmedcentral.nih.gov/articlerender.fcgi?artid=3814186\& too $1=$ pmcentrez\&rendertype $=$ abstract $>$. Accessed: Jul. 09, 2014. doi:10.1016/j.tig.2011.08.002.

PASQUE, V. et al. Efficiencies and mechanisms of nuclear reprogramming. Cold Spring Harbor Symposia on Quantitative Biology, v.75, p.189-200, Jan. 2010. Available from: <http:// www.pubmedcentral.nih.gov/articlerender.fcgi?artid=3833051\& tool $=$ pmcentrez\&rendertype $=$ abstract $>$. Accessed: Jul. 09, 2014. doi: $10.1101 / \mathrm{sqb} .2010 .75 .002$

PORTELA, A.; ESTELLER, M. Epigenetic modifications and human disease. Nature Biotechnology, v.28, n.10, p.1057-1068, Oct. 2010. Available from: <http://www.ncbi.nlm.nih.gov/pubmed/20944598>. Accessed: Jul. 09, 2014. doi:10.1038/nbt.1685.

RAPOSO, G.; STOORVOGEL, W. Extracellular vesicles: exosomes, microvesicles, and friends. Journal of Cell Biology, v.200, n.4, p.373-383, Feb. 2013. Available from: <http://www. ncbi.nlm.nih.gov/pubmed/23420871>. Accessed: Jul. 09, 2014. doi:10.1083/jcb.201211138.

REIK, W. et al. Epigenetic reprogramming in mammalian development. Science, v.293, n.5532, p.1089-1093, Ago 2001. Available from: <http://www.ncbi.nlm.nih.gov/ pubmed/11498579>. Accessed: Jul. 09, 2014. doi:10.1126/ science. 1063443 .

RIZOS, D. et al. Consequences of bovine oocyte maturation, fertilization or early embryo development in vitro versus in vivo: implications for blastocyst yield and blastocyst quality. Molecular Reproduction and Development, v.61, n.2, p.234248, Feb. 2002. Available from: <http://www.ncbi.nlm.nih.gov/ pubmed/11803560>. Accessed: Feb. 21, 2014. doi:10.1002/ mrd.1153.

SAADELDIN, I.M., et al. Improvement of cloned embryos development by co-culturing with parthenotes: a possible role of exosomes/microvesicles for embryos paracrine communication. Cellular Reprogramming, v.16, n.3, p.223234, Jun. 2014. Available from: <http://www.ncbi.nlm.nih.gov/ pubmed/24773308>. Accessed: Dec. 01, 2014. doi: 10.1089/ cell.2014.0003

SANG, Q. et al. Identification of microRNAs in human follicular fluid: characterization of microRNAs that govern steroidogenesis in vitro and are associated with polycystic ovary syndrome in vivo. Journal of Clinical Endocrinology and Metabolism, v.98, n.7, p.3068-3079, Jul. 2013. Available from: $<$ http://www. ncbi.nlm.nih.gov/pubmed/23666971>. Accessed: Jul. 02, 2014. doi:10.1210/jc.2013-1715.

SANGALLI, J.R. et al. Development to term of cloned cattle derived from donor cells treated with valproic acid. PloS One, v.9, n.6, p.e101022, Jan. 2014. Available from: <http://www. pubmedcentral.nih.gov/articlerender.fcgi? artid $=4069182 \&$ too l=pmcentrez\&rendertype=abstract $>$. Accessed: Jul. 09, 2014. doi:10.1371/journal.pone.0101022.

SANGALLI, J.R. et al. Treatment of nuclear-donor cells or cloned zygotes with chromatin-modifying agents increases histone acetylation but does not improve full-term development of cloned cattle. Cellular reprogramming, v.14, n.3, p.235247, Jun. 2012. Available from: <http://www.ncbi.nlm.nih.gov/ pubmed/22468998>. Accessed: Jul. 09, 2014. doi:10.1089/ cell.2011.0079.

SANTOS, F. et al. Dynamic reprogramming of DNA methylation in the early mouse embryo. Developmental Biology, v.241, n.1, p.172-182, Jan. 2002. Available from: <http://www.ncbi.nlm.nih. gov/pubmed/11784103>. Accessed: Jul. 09, 2014. doi:10.1006/ dbio.2001.0501.

SANTOS, F. etal. Epigenetic marking correlates with developmental potential in cloned bovine preimplantation embryos. Current Biology: CB, v.13, n.13, p.1116-1121, Jul. 2003. Available from: $<$ http://www.ncbi.nlm.nih.gov/pubmed/12842010>. Accessed: Jul. 09, 2014. doi: 10.1016/S0960-9822(03)00419-6.

SMITH, L.C. et al. Developmental and epigenetic anomalies in cloned cattle. Reproduction in Domestic Animals, v.47, Suppl.4, p.107-114, Ago. 2012. Available from: <http://www.ncbi.nlm.nih. gov/pubmed/22827358>. Accessed: Jan. 28, 2014. doi:10.1111/ j.1439-0531.2012.02063.x.

SOHEL, M.M.H. et al. Exosomal and non-exosomal transport of extra-cellular microRNAs in follicular fluid: implications for bovine oocyte developmental competence. PloS one, v.8, n.11, p.e78505, Jan. 2013a. Available from: <http://www.pubmedcentral.nih. gov/articlerender.fcgi? artid=3817212\&tool=pmcentrez\&rende rtype $=$ abstract $>$. Accessed: Jun. 19, 2014. doi:10.1371/journal. pone.0078505.

TANNETTA, D. et al. Extracellular vesicles and reproductionpromotion of successful pregnancy. Cellular and Molecular Immunology, v.11, n.6, p. 548-563, Jun. 2014. Available from: $<$ http://www.ncbi.nlm.nih.gov/pubmed/24954226>. Accessed: Dec. 03, 2014. doi: 10.1038/cmi.2014.42.

VAJTA, G. et al. Embryo culture: can we perform better than nature? Reproductive Biomedicine Online, v.20, n.4, p.453469, Apr. 2010. Available from: <http://www.ncbi.nlm.nih.gov/ pubmed/20202911>. Accessed: Jul. 09, 2014. doi:10.1016/j. rbmo.2009.12.018.

VAN WAGTENDONK-DE LEEUW, A.M. et al. Abnormal offspring following in vitro production of bovine preimplantation embryos: A field study. Theriogenology, v.49, n.5, p.883894, 1998. Available from: <http://www.ncbi.nlm.nih.gov/ pubmed/1073209>. Accessed: Jul. 09, 2014. doi:10.1016/s0093$691 \times(98) 00038-7$

WOSSIDLO, M. et al. 5-Hydroxymethylcytosine in the mammalian zygote is linked with epigenetic reprogramming. Nature communications, v.2, p.241, Jan. 2011. Available from: $<$ http://www.ncbi.nlm.nih.gov/pubmed/21407207>. Accessed: Jul. 09, 2014. doi:10.1038/ncomms 1240 . 